Brit. Heart F., 1967, 29, 396.

\title{
Determination of Pressure in the Pulmonary Artery by External Graphic Recordings
}

\author{
LUIS BURSTIN*
}

\begin{abstract}
From the Department of Phonocardiography, Institute of Cardiology, Mexico, and the Department of Physiopathology, University of Costa Rica, San fosé, Costa Rica
\end{abstract}

Pulmonary hypertension is a fundamental problem in the study of diseases of the heart and lungs. Because of its importance with regard to pathogenesis, clinical manifestations, and indications for surgery, it has been the object of numerous studies. At present, however, quantitative determination of pulmonary arterial pressure can be made satisfactorily only by cardiac catheterization.

A preliminary communication on a new method for the determination of the systolic pressure in the pulmonary artery by external graphic recordings (Burstin, 1963) was presented at the Fourth World Congress of Cardiology in Mexico in 1962. The results of two years' experience with this method are presented here.

\section{METHOD}

The determination of systolic pulmonary arterial pressure (SPAP) by external graphic recordings is based on the measurement of the phase of isometric relaxation of the right ventricle, which begins with the closure of the pulmonary valve and ends with the opening of the tricuspid (IIp-T interval). To measure this interval several points of reference on the graphic recordings are used (Fig. 1). The closure of the pulmonary valve is represented by the pulmonary component of the second sound of the phonocardiogram (IIp), which is easily identifiable following the aortic component (IIa), especially when there is pulmonary hypertension or the second sound is split. With paradoxical splitting of the second sound, the vertex of the incisura of the carotid pulse is useful in identifying $\mathrm{IIa}$, and, therefore, by exclusion, IIp. When it is difficult to distinguish IIp, the recording of the external cardiogram of the pulmonary artery (Fishleder and Friedland, 1957) frequently demonstrates a notch that signals the closure of the pulmonary valve (Fig. 2). The opening of the tricuspid

Received January 3, 1966.

^ Present address: Apartado 1496, San José, Costa Rica. valve can be identified on several external recordings: point $2 \mathrm{~b}$ (point 0 ) of the right ventricular cardiogram (Luisada, 1953), the vertex of the $v$ wave of the phlebogram (Hartman, 1960), and the functional tricuspid opening snap which is seen in atrial septal defect with large shunt (Leatham and Gray, 1956). In some cases it is possible to record these three points of reference simultaneously (Fig. 1).

The duration of the IIp-T interval is determined by three factors: (1) right atrial pressure, (2) heart rate, and (3) systolic pulmonary arterial pressure. The right atrial pressure determines the moment of opening of the tricuspid valve. An increased right atrial pressure causes the tricuspid valve to open earlier and thereby shortens the IIp-T interval. Nevertheless, in cases where there is no tricuspid stenosis, insufficiency, or right heart failure, the right atrial pressure remains normal even though the pulmonary arterial pressure may be raised. This is demonstrated in Fig. 3 which shows the results of a study in which right atrial pressures were measured in 100 patients, with varying levels of pulmonary arterial pressure. It is considered, therefore, that in the absence of the factors mentioned above, the right atrial pressure is constant and does not exert a significant influence on the IIp-T interval.

The heart rate is an important factor in the duration of all phases of the cardiac cycle. Though it is not known with certainty if the duration of the IIp-T interval diminishes in a linear manner with increasing heart rate, it is thought that the two factors are inversely proportional, and this has been confirmed by our own experience and recently by that of others (Prati et al., 1964).

According to accepted theory, the systolic pulmonary arterial pressure (SPAP) determines the time of closure of the pulmonary valve, which occurs earlier with increasing pulmonary arterial pressure. In accordance with this concept, the IIp-T interval would be prolonged by an increased SPAP because of early closure of the pulmonary valve. In the course of the investigation it was confirmed that an increasing SPAP prolonged the IIp-T interval, but that the mechanism involved was different. An increase of SPAP does not significantly affect the closure of the pulmonary valve, but does 396 


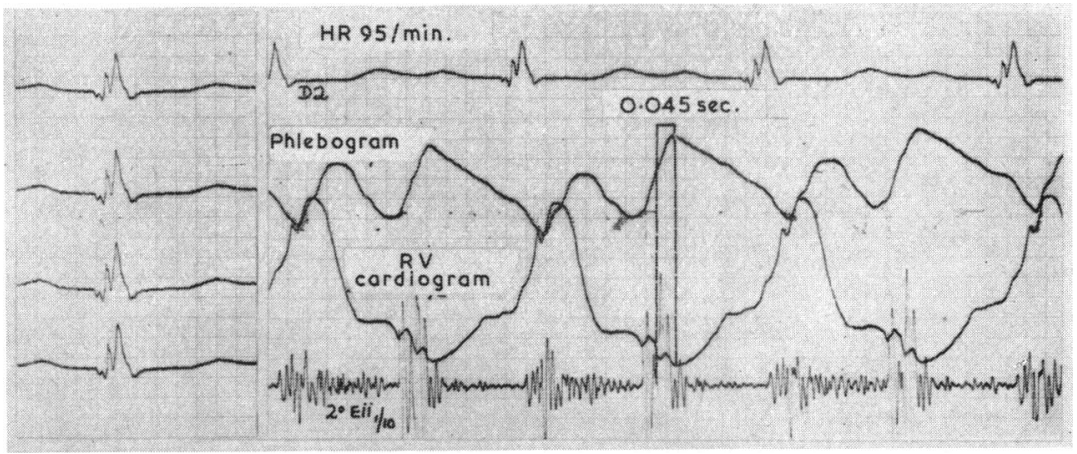

FIG. 1.-Atrial septal defect. From above: electrocardiogram, phlebogram, right ventricular cardiogram, and phonocardiogram at the pulmonary area. Recording velocity: $100 \mathrm{~mm}$. $/ \mathrm{sec}$. Note the synchronous recording of the vertex of the $\mathrm{v}$ wave of the phlebogram, point 0 of the right ventricular cardiogram, and the functional tricuspid opening snap. The pulmonary component of the second sound is well demonstrated.

On the left: channel synchronization. Heart rate 95 a minute; IIp-T interval 0.045 sec.

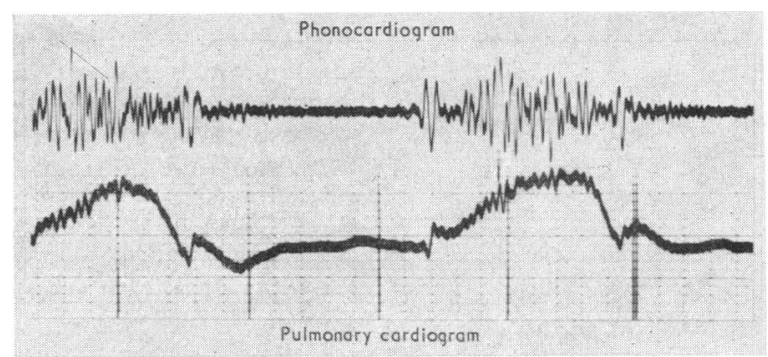

Fig. 2.-Above: phonocardiogram. Below: the vertex of the dicrotic wave of the pulmonary cardiogram identifies the moment of closure of the pulmonary valve.

SPAP causes an equal rise in right ventricular pressure, and once the pulmonary valve has closed, the pressure in the right ventricle must fall from a higher point in order to reach the pressure of the right atrium. Since right atrial pressure is kept constant, the opening of the tricuspid valve is delayed and the IIp-T interval is prolonged in a manner proportional to the increase in SPAP (Burstin, 1963) (Fig. 4).

Assuming that the IIp-T interval is determined by the heart rate and the SPAP, a table can be constructed in which the SPAP is determined from the first two factors. Two cases published by Hartman in 1960 formed the basis for the construction of this table. One of these recordings is shown in Fig. 5 in which the vertex of the $v$ wave of the phlebogram appears $0.11 \mathrm{sec}$. after IIp, the heart rate is 75 per minute, and the SPAP 80 $\mathrm{mm}$. Hg. The other (Fig. 6) shows the vertex of the $v$ wave of the phlebogram 0.04 sec. after the closure of the pulmonary valve, with a normal SPAP and a heart rate of 90 per minute (Hartman, 1960). From these two cases Fig. 7 was designed so that the duration of IIp-T at constant pulmonary pressure would be inversely proportional to the heart rate, and that at constant heart rate it would be directly proportional to the SPAP. The heart rate is measured in units of five beats a minute and IIp-T in intervals of 0.005 sec.
The first case studied using this table is shown inFig. 8. The SPAP, determined by cardiac catheterization, was $117 \mathrm{~mm}$. $\mathrm{Hg}$, with a heart rate of 90 per minute. According to Fig. 7 the IIp-T interval should be about $0.13 \mathrm{sec}$, and study by external recordings, as previously described, revealed a IIp-T interval of 0.135 sec. This case demonstrated that the basis for the method

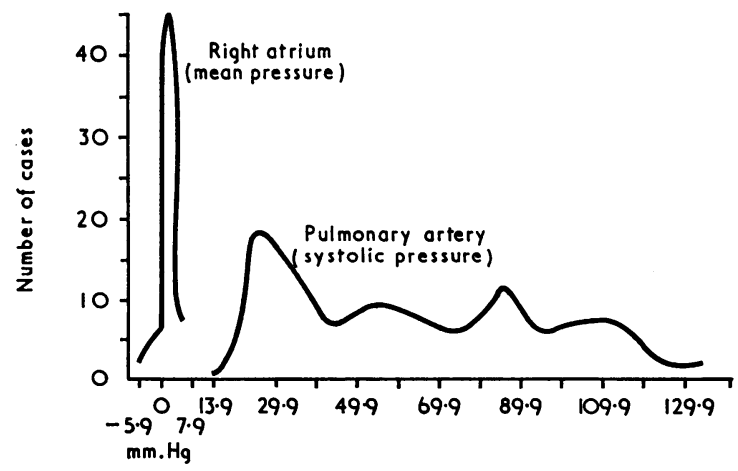

FIG. 3.-Right atrial pressure and systolic pulmonary arterial pressure in 100 cases. 
was fundamentally correct and that further cases had to be studied to correlate the values calculated from the table with those obtained by cardiac catheterization.

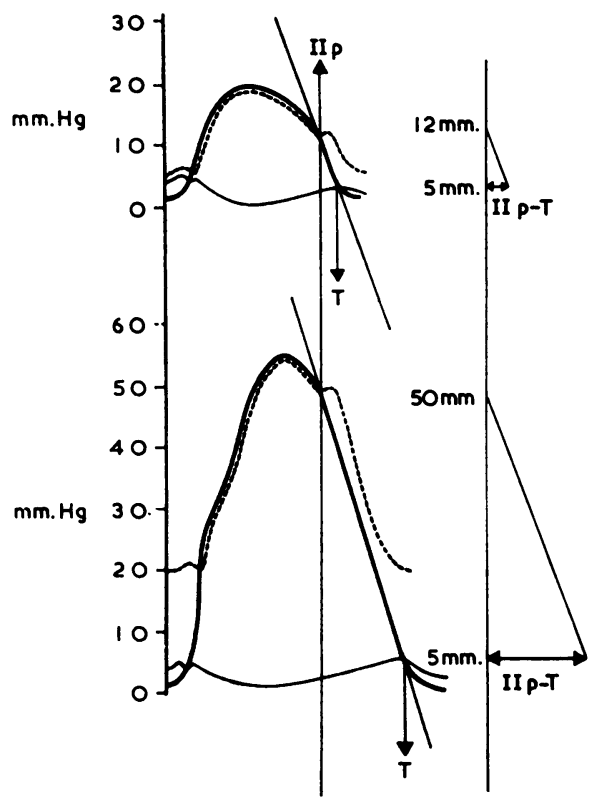

Frg. 4.-Mechanism by which an increase in the systolic pulmonary arterial pressure produces prolongation of the IIp-T interval. Above : heavy line = right ventricular pressure; broken line = pulmonary arterial pressure; light line $=$ right atrial pressure. Hæmodynamic scheme of a case with normal systolic pulmonary arterial pressure. Note the point of closure of the pulmonary valve (IIp) and the opening of the tricuspid valve $(T)$. On the right the duration of the IIp-T interval corresponding to this example. Below: example of a case with pulmonary hypertension. At the same rate of fall of right ventricular pressure more time is needed to reach the level of right atrial pressure, thereby retarding opening of the tricuspid valve and prolonging the duration of the IIp-T interval.

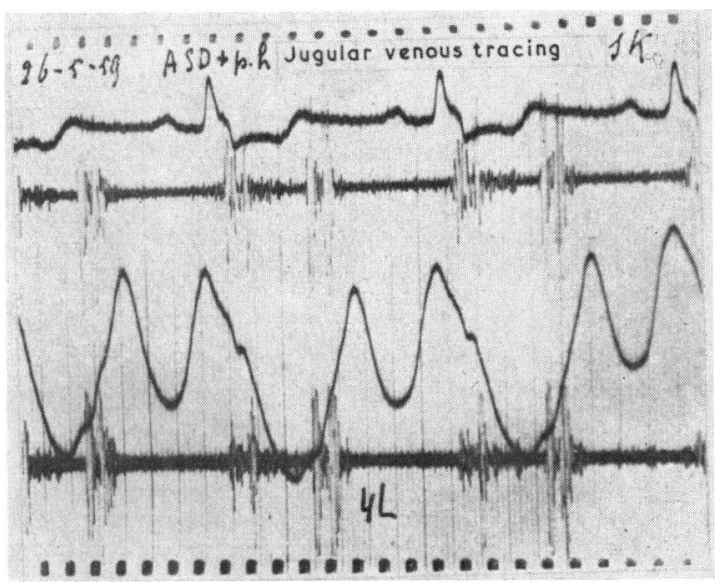

FIG. 5.-From Hartman (1960). See text.

\section{SUBJECTS}

One hundred and twenty cases were studied without selection with respect to type of cardiac disease or severity of pulmonary hypertension, though patients with tricuspid insufficiency, stenosis, or right heart failure, as determined clinically and by cardiac catheterization, were eliminated. Of these, 80 had heart disease and $\mathbf{4 0}$ were healthy subjects with negative clinical histories and a normal electrocardiogram and chest radiograph. Table I shows the distribution of cases in the group with heart disease, which included 61 with pulmonary hypertension (more than $30 \mathrm{~mm} . \mathrm{Hg}$ ) and 19 with normal pulmonary pressures. In the first 50 cases the greatest time between study by external recordings and cardiac catheterization was five days. Both studies were performed simultaneously in the remaining cases.

Equipment included a 4-channel Elema 42-B with Infraton receivers of the Boucke-Brecht type, a highsensitivity electromagnetic microphone, and a 6-channel Cardirex with the same receivers. Both instruments were of the direct recording type. In all patients

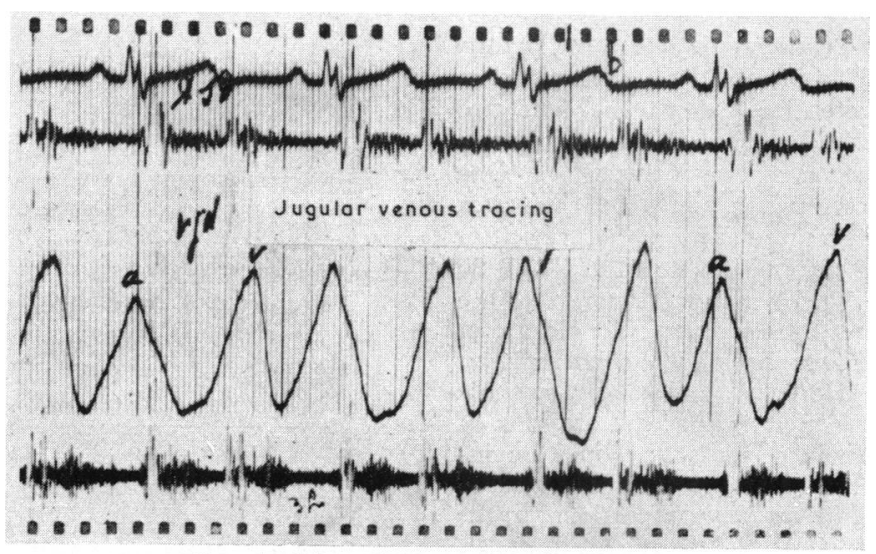

FIG. 6.-From Hartman (1960). See text. 


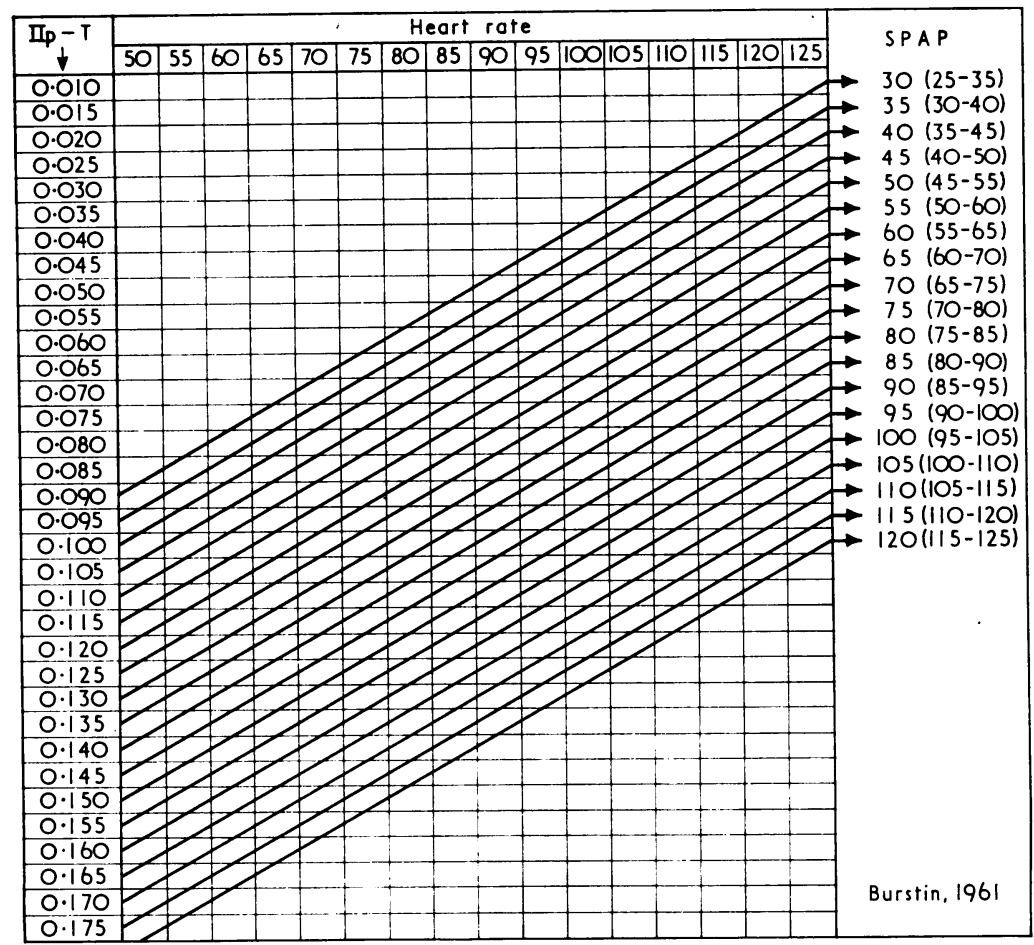

Fig. 7.-Illustrates how systolic pulmonary arterial pressure (SPAP) can be calculated from the IIp-T interval heart rate. (Originally published in Proceedings of IV World Congress of Cardiology in 1962.)

simultaneous recordings were made of the electrocardiogram (standard lead II), jugular phlebogram, and/or right ventricular cardiogram, and phonocardiogram, at a velocity of $100 \mathrm{~mm}$./sec. in the first 50 cases and of $200 \mathrm{~mm}$. $/ \mathrm{sec}$. in the remainder.

\section{Results AND Conclusions}

The results obtained in the 40 subjects with normal hearts are shown in Table II. In these, the figure for SPAP from Fig. 7 was less than $30 \mathrm{~mm}$. Hg. Table III lists the results obtained from the 19 patients in the group with cardiac disease and SPAP less than $30 \mathrm{~mm}$. $\mathrm{Hg}$, and Table IV gives data from the 61 patients in the group with cardiac disease and pulmonary hypertension. Fig. 14 presents the correlation between the figures for SPAP as determined from Fig. 7 and from cardiac: catheterization in these 61 patients. Some examples.

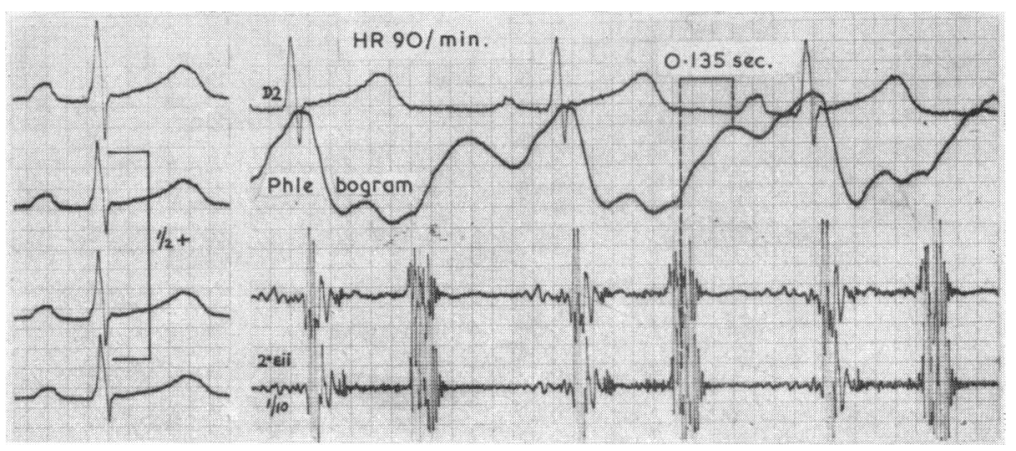

FIG. 8.-First case studied using Fig. 7: IIp-T $0.135 \mathrm{sec}$, heart rate 90 a minute. The systolic pulmonary arterial pressure, as read from Fig. 7, falls between 115 and $120 \mathrm{~mm}$. Hg. A pulmonary systolic pressure of $117 \mathrm{~mm}$. Hg was recorded at cardiac catheterization. 
of the cases studied are shown in Fig. 1 and 8-13.

In order to use this method more widely, it would be necessary to establish a correction factor for cases in which the right atrial pressure is raised. This factor would probably be derived from the

TABLE I

DISTRIBUTION OF CASES BY TYPE OF HEART DISEASE

\begin{tabular}{l|c}
\hline & $\begin{array}{c}\text { No. of } \\
\text { cases }\end{array}$ \\
\hline Mitral stenosis and insufficiency & 15 \\
Patent ductus arteriosus & 12 \\
Atrial septal defect & 10 \\
Ventricular septal defect & 10 \\
Mitral stenosis & 8 \\
Mitral stenosis and insufficiency plus aortic regurgitation & 5 \\
Pure pulmonary stenosis & 5 \\
Aortic stenosis & 3 \\
Coarctation of the aorta & 2 \\
Tetralogy of Fallot & 2 \\
Mitral stenosis and insufficiency plus aortic stenosis & 2 \\
Primary pulmonary hypertension & 2 \\
Eisenmenger's syndrome & 2 \\
Mitral stenosis and aortic stenosis & 1 \\
Ventricular septal defect with atrial septal defect & 1 \\
\hline \multicolumn{1}{c}{ Total } & 80 \\
\hline
\end{tabular}

brachial venous pressure and would permit the use of Fig. 7 in cases with tricuspid stenosis and/or insufficiency, or right heart failure. It would be interesting also to verify that the rate of fall of right ventricular pressure is uniform and independent of the level of SPAP and the type of heart disease, or to see if variation exists with relation to these two factors. In addition, the study of a greater number of cases would permit necessary corrections to be made in such a manner as to increase the accuracy of this method and of Fig. 7.

TABLE II

RESULTS OF 40 CASES WITHOUT HEART DISEASE

\begin{tabular}{|c|c|c|c|}
\hline Case No. & $\begin{array}{l}\text { Age } \\
\text { (yr.) }\end{array}$ & $\begin{array}{c}\text { Heart } \\
\text { rate/min. }\end{array}$ & $\underset{(\mathrm{sec} .)}{\mathrm{IIp}-\mathrm{T}}$ \\
\hline $\begin{array}{r}1 \\
2 \\
3 \\
4 \\
5 \\
6 \\
7 \\
8 \\
9 \\
10 \\
11 \\
12 \\
13 \\
14 \\
15 \\
16 \\
17 \\
18 \\
19 \\
20 \\
21 \\
22 \\
23 \\
24 \\
25 \\
26 \\
27 \\
28 \\
29 \\
30 \\
31 \\
32 \\
33 \\
34 \\
35 \\
36 \\
37 \\
38 \\
39 \\
40\end{array}$ & $\begin{array}{r}9 \\
2 \\
10 \\
21 \\
19 \\
11 \\
21 \\
8 \\
15 \\
35 \\
12 \\
20 \\
15 \\
45 \\
52 \\
18 \\
31 \\
9 \\
20 \\
29 \\
30 \\
32 \\
27 \\
28 \\
7 \\
30 \\
11 \\
8 \\
20 \\
25 \\
21 \\
11 \\
12 \\
19 \\
23 \\
19 \\
5 \\
51 \\
40 \\
12\end{array}$ & 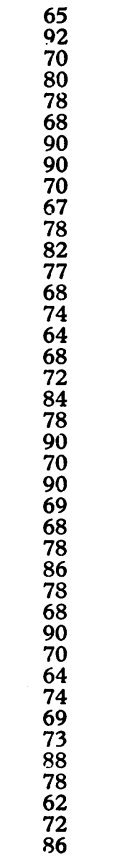 & $\begin{array}{l}0.065 \\
0.04 \\
0.04 \\
0.04 \\
0.05 \\
0.035 \\
0.03 \\
0.045 \\
0.06 \\
0.05 \\
0.05 \\
0.05 \\
0.02 \\
0.04 \\
0.05 \\
0.07 \\
0.065 \\
0.06 \\
0.05 \\
0.05 \\
0.04 \\
0.06 \\
0.03 \\
0.06 \\
0.03 \\
0.05 \\
0.03 \\
0.05 \\
0.06 \\
0.04 \\
0.06 \\
0.07 \\
0.05 \\
0.065 \\
0.05 \\
0.045 \\
0.055 \\
0.07 \\
0.06 \\
0.045\end{array}$ \\
\hline
\end{tabular}

Indirect pulmonary systolic pressure was less than $30 \mathrm{~mm} . \mathrm{Hg}$ in cvery case.

TABLE III

RESULTS IN 19 CASES WITH CARDIAC DISEASE

\begin{tabular}{|c|c|c|c|c|c|}
\hline Case No. & $\begin{array}{c}\text { Age } \\
\text { (yr.) }\end{array}$ & Heart rate/min. & IIp-T (sec.) & $\begin{array}{c}\text { Pulmonary } \\
\text { systolic } \\
\text { pressure } \\
\text { (mm. Hg) } \\
\text { (catheterization) }\end{array}$ & Diagnosis \\
\hline $\begin{array}{r}1 \\
2 \\
3 \\
4 \\
5 \\
6 \\
7 \\
8 \\
9 \\
10 \\
11 \\
12 \\
13 \\
14 \\
15 \\
16 \\
17 \\
18 \\
19\end{array}$ & $\begin{array}{r}17 \\
19 \\
17 \\
14 \\
19 \\
9 \\
10 \\
9 \\
29 \\
9 \\
7 \\
14 \\
9 \\
11 \\
8 \\
17 \\
21 \\
20 \\
11\end{array}$ & $\begin{array}{r}78 \\
62 \\
60 \\
100 \\
85 \\
95 \\
85 \\
70 \\
65 \\
90 \\
75 \\
100 \\
110 \\
70 \\
80 \\
100 \\
75 \\
90 \\
65\end{array}$ & $\begin{array}{l}0.04 \\
0.05 \\
0.05 \\
0.03 \\
0.03 \\
0.04 \\
0.04 \\
0.05 \\
0.06 \\
0.03 \\
0.05 \\
0.03 \\
0.02 \\
0.06 \\
0.05 \\
0.03 \\
0.06 \\
0.03 \\
0.05\end{array}$ & $\begin{array}{l}21 \\
12 \\
10 \\
12 \\
16 \\
18 \\
20 \\
16 \\
22 \\
14 \\
13 \\
24 \\
22 \\
19 \\
18 \\
15 \\
27 \\
19 \\
20\end{array}$ & $\begin{array}{l}\text { Ventricular septal defect (Roger) } \\
\text { Pure pulmonary stenosis } \\
\text { Pure pulmonary stenosis } \\
\text { Pure pulmonary stenosis } \\
\text { Aortic stenosis } \\
\text { Aortic stenosis } \\
\text { Coarctation of aorta } \\
\text { Ventricular septal defect (Roger) } \\
\text { Mitral stenosis } \\
\text { Coarctation of aorta } \\
\text { Fallot } \\
\text { Atrial septal defect } \\
\text { Atrial septal defect } \\
\text { Aortic stenosis } \\
\text { Fallot } \\
\text { Pure pulmonary stenosis } \\
\text { Mitral stenosis and insufficiency } \\
\text { Pure pulmonary stenosis } \\
\text { Ventricular septal deffect (Roger) }\end{array}$ \\
\hline
\end{tabular}

Indirect pulmonary systolic pressure was less than $30 \mathrm{~mm} . \mathbf{H g}$ in every case. 
TABLE IV

RESULTS IN 61 CASES WITH CARDIAC DISEASE AND RAISED SYSTOLIC PULMONARY ARTERIAL PRESSURE

\begin{tabular}{|c|c|c|c|c|c|c|}
\hline \multirow[t]{2}{*}{ Case No. } & \multirow[t]{2}{*}{$\begin{array}{l}\text { Age } \\
\text { (yr.) }\end{array}$} & \multirow[t]{2}{*}{$\begin{array}{l}\text { Heart } \\
\text { rate/min. }\end{array}$} & \multirow[t]{2}{*}{$\underset{(\text { sec.) }}{\operatorname{IIp}-T}$} & \multicolumn{2}{|c|}{$\begin{array}{l}\text { Pulmonary systolic } \\
\text { pressure (mm. Hg) }\end{array}$} & \multirow[t]{2}{*}{ Diagnosis } \\
\hline & & & & Indirect & $\begin{array}{c}\text { Catheteri- } \\
\text { zation }\end{array}$ & \\
\hline $\begin{array}{r}1 \\
2 \\
3 \\
4 \\
5 \\
6 \\
7 \\
8 \\
9 \\
10 \\
11 \\
12 \\
13 \\
14 \\
15 \\
16 \\
17\end{array}$ & $\begin{array}{r}14 \\
9 \\
18 \\
19 \\
21 \\
12 \\
13 \\
9 \\
21 \\
19 \\
12 \\
8 \\
21 \\
8 \\
19 \\
32 \\
22\end{array}$ & $\begin{array}{r}80 \\
90 \\
95 \\
75 \\
100 \\
95 \\
90 \\
93 \\
75 \\
115 \\
65 \\
75 \\
85 \\
65 \\
90 \\
72 \\
70\end{array}$ & $\begin{array}{l}0.06 \\
0.055 \\
0.05 \\
0.07 \\
0.05 \\
0.06 \\
0.06 \\
0.06 \\
0.08 \\
0.04 \\
0.09 \\
0.08 \\
0.07 \\
0.09 \\
0.065 \\
0.085 \\
0.09\end{array}$ & $\begin{array}{l}30-35 \\
35-40 \\
35-40 \\
35-40 \\
40-45 \\
40-45 \\
40-45 \\
40-45 \\
45-50 \\
45-50 \\
45-50 \\
45-50 \\
45-50 \\
45-50 \\
45-50 \\
50-55 \\
50-55\end{array}$ & $\begin{array}{l}32 \\
35 \\
35 \\
40 \\
52 \\
36 \\
42 \\
35 \\
44 \\
40 \\
46 \\
56 \\
49 \\
62 \\
64 \\
50 \\
52\end{array}$ & $\begin{array}{l}\text { Atrial septal defect } \\
\text { Patent ductus arteriosus } \\
\text { Atrial septal defect } \\
\text { Mitral stenosis } \\
\text { Atrial septal defect } \\
\text { Atrial septal defect } \\
\text { Mitral stenosis } \\
\text { Atrial septal defect } \\
\text { Mitral stenosis and insufficiency } \\
\text { Ventricular septal defect } \\
\text { Atrial septal defect } \\
\text { Patent ductus arteriosus } \\
\text { Mitral stenosis and insufficiency } \\
\text { Atrial septal defect } \\
\text { Mitral stenosis and insufficiency } \\
\text { Mitral stenosis } \\
\text { Mitral stenosis and insufficiency and aortic regurgi- } \\
\text { tation }\end{array}$ \\
\hline $\begin{array}{l}18 \\
19 \\
20 \\
21 \\
22 \\
23 \\
24 \\
25 \\
26 \\
27 \\
28 \\
29 \\
30 \\
31 \\
32 \\
33 \\
34 \\
35 \\
36 \\
37 \\
38\end{array}$ & $\begin{array}{r}16 \\
19 \\
7 \\
60 \\
9 \\
6 \\
20 \\
27 \\
11 \\
7 \\
23 \\
29 \\
12 \\
24 \\
28 \\
10 \\
22 \\
32 \\
14 \\
34 \\
28\end{array}$ & $\begin{array}{r}100 \\
80 \\
90 \\
65 \\
105 \\
65 \\
95 \\
100 \\
70 \\
75 \\
80 \\
100 \\
90 \\
105 \\
95 \\
105 \\
60 \\
100 \\
80 \\
110 \\
95\end{array}$ & $\begin{array}{l}0.06 \\
0.08 \\
0.07 \\
0.0975 \\
0.06 \\
0.10 \\
0.07 \\
0.065 \\
0.10 \\
0.095 \\
0.09 \\
0.07 \\
0.08 \\
0.07 \\
0.08 \\
0.07 \\
0.12 \\
0.08 \\
0.10 \\
0.07 \\
0.09\end{array}$ & $\begin{array}{l}50-55 \\
50-55 \\
50-55 \\
55-60 \\
55-60 \\
55-60 \\
55-60 \\
55-60 \\
60-65 \\
60-65 \\
60-65 \\
60-65 \\
60-65 \\
65-70 \\
65-70 \\
65-70 \\
70-75 \\
70-75 \\
70-75 \\
70-75 \\
75-80\end{array}$ & $\begin{array}{l}45 \\
40 \\
62 \\
55 \\
56 \\
49 \\
67 \\
64 \\
65 \\
62 \\
54 \\
56 \\
76 \\
55 \\
66 \\
67 \\
65 \\
68 \\
72 \\
76 \\
84\end{array}$ & $\begin{array}{l}\text { Mitral stenosis } \\
\text { Mitral stenosis and insufficiency } \\
\text { Ventricular septal defect } \\
\text { Atrial septal defect } \\
\text { Ventricular septal defect } \\
\text { Patent ductus arteriosus } \\
\text { Mitral stenosis and insufficiency } \\
\text { Mitral stenosis and insufficiency } \\
\text { Patent ductus arteriosus } \\
\text { Patent ductus arteriosus } \\
\text { Mitral stenosis } \\
\text { Mitral stenosis and insufficiency } \\
\text { Patent ductus arteriosus } \\
\text { Mitral stenosis and insufficiency } \\
\text { Mitral stenosis and insufficiency and aortic stenosis } \\
\text { Patent ductus arteriosus } \\
\text { Mitral stenosis and insufficiency } \\
\text { Mitral stenosis } \\
\text { Patent ductus arteriosus } \\
\text { Mitral stenosis and insufficiency } \\
\text { Mitral stenosis and insufficiency and aortic regurgi- }\end{array}$ \\
\hline $\begin{array}{l}39 \\
40 \\
41 \\
42 \\
43\end{array}$ & $\begin{array}{l}11 \\
29 \\
19 \\
30 \\
16\end{array}$ & $\begin{array}{r}75 \\
90 \\
100 \\
95 \\
95\end{array}$ & $\begin{array}{l}0 \cdot 11 \\
0 \cdot 10 \\
0 \cdot 09 \\
0 \cdot 095 \\
0 \cdot 10\end{array}$ & $\begin{array}{l}75-80 \\
80-85 \\
80-85 \\
80-85 \\
85-90\end{array}$ & $\begin{array}{l}78 \\
94 \\
85 \\
82 \\
82\end{array}$ & $\begin{array}{l}\text { tation } \\
\text { Patent ductus arteriosus } \\
\text { Mitral stenosis and aortic stenosis } \\
\text { Mitral stenosis and insufficiency } \\
\text { Mitral stenosis and insufficiency } \\
\text { Mitral stenosis and insufficiency and aortic regurgi- } \\
\text { tation }\end{array}$ \\
\hline $\begin{array}{l}44 \\
45 \\
46 \\
47 \\
48 \\
49\end{array}$ & $\begin{array}{r}4 \\
15 \\
11 \\
32 \\
9 \\
29\end{array}$ & $\begin{array}{r}85 \\
100 \\
80 \\
80 \\
90 \\
105\end{array}$ & $\begin{array}{l}0 \cdot 11 \\
0 \cdot 10 \\
0 \cdot 12 \\
0 \cdot 12 \\
0 \cdot 12 \\
0 \cdot 10\end{array}$ & $\begin{array}{l}85-90 \\
90-95 \\
90-95 \\
90-95 \\
90-95 \\
95-100\end{array}$ & $\begin{array}{r}88 \\
90 \\
93 \\
102 \\
87 \\
94\end{array}$ & $\begin{array}{l}\text { Patent ductus arteriosus } \\
\text { Mitral stenosis and insufficiency } \\
\text { Ventricular septal defect } \\
\text { Mitral stenosis } \\
\text { Patent ductus arteriosus } \\
\text { Mitral stenosis and insufficiency and aortic regurgi- } \\
\text { tation }\end{array}$ \\
\hline $\begin{array}{l}\mathbf{5 0} \\
51 \\
52 \\
53 \\
54 \\
55 \\
56\end{array}$ & $\begin{array}{r}21 \\
6 \\
8 \\
9 \\
10 \\
17 \\
38\end{array}$ & $\begin{array}{r}85 \\
95 \\
85 \\
110 \\
115 \\
85 \\
75\end{array}$ & $\begin{array}{l}0 \cdot 12 \\
0 \cdot 11 \\
0 \cdot 12 \\
0 \cdot 10 \\
0 \cdot 10 \\
0 \cdot 13 \\
0 \cdot 14\end{array}$ & $\begin{array}{r}95-100 \\
95-100 \\
95-100 \\
100-105 \\
105-110 \\
105-110 \\
105-110\end{array}$ & $\begin{array}{r}82 \\
96 \\
98 \\
94 \\
98 \\
104 \\
106\end{array}$ & $\begin{array}{l}\text { Mitral stenosis and insufficiency } \\
\text { Ventricular septal defect } \\
\text { Ventricular septal defect } \\
\text { Ventricular septal defect } \\
\text { Ventricular septal defect and atrial septal defect } \\
\text { Patent ductus arteriosus } \\
\text { Mitral stenosis and insufficiency and aortic regurgi- } \\
\text { tation }\end{array}$ \\
\hline $\begin{array}{l}57 \\
58 \\
59 \\
60 \\
61\end{array}$ & $\begin{array}{r}34 \\
8 \\
7 \\
6 \\
9\end{array}$ & $\begin{array}{r}105 \\
95 \\
90 \\
80 \\
90\end{array}$ & $\begin{array}{l}0 \cdot 11 \\
0 \cdot 12 \\
0 \cdot 13 \\
0 \cdot 14 \\
0 \cdot 135\end{array}$ & $\begin{array}{l}105-110 \\
105-110 \\
110-115 \\
110-115 \\
115-120\end{array}$ & $\begin{array}{l}108 \\
108 \\
112 \\
110 \\
117\end{array}$ & $\begin{array}{l}\text { Mitral stenosis and insufficiency and aortic stenosis } \\
\text { Primary pulmonary hypertension } \\
\text { Eisenmenger's syndrome } \\
\text { Eisenmenger's syndrome } \\
\text { Primary pulmonary hypertension }\end{array}$ \\
\hline
\end{tabular}




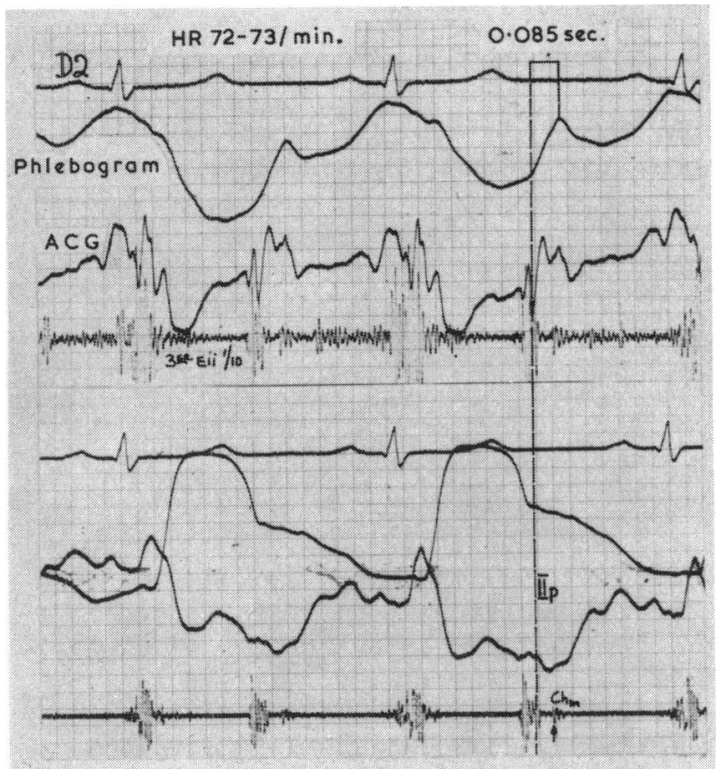

FIG. 9.-Case 16 from Table IV. IIp-T 0.085 sec., heart rate 72-73 per minute. Calculated systolic pulmonary arterial pressure 50-55 mm. $\mathrm{Hg}$; cardiac catheterization $50 \mathrm{~mm}$. $\mathrm{Hg}$. $\mathrm{ACG}=$ apex cardiogram.

\section{SUMMARY}

A method for determining the systolic pulmonary arterial pressure by external graphic recordings is described. The technique is based upon measuring the phase of isometric relaxation of the right ventricle (IIp-T interval). The factors that determine the duration of the IIp-T interval are: (1) the right atrial pressure which, in the absence of tricuspid stenosis or insufficiency or right heart failure, re-

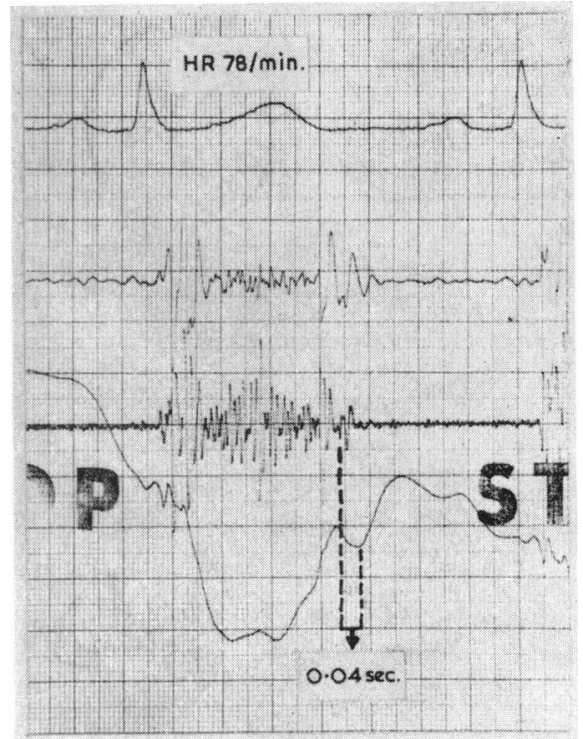

Fig. 11.-Case 1 from Table III. IIp-T 0.04 sec., heart rate 78 per minute. Calculated systolic pulmonary arterial pressure less than $30 \mathrm{~mm}$. Hg; cardiac catheterization $21 \mathrm{~mm}$. $\mathrm{Hg}$.

mains normal; (2) the systolic pulmonary arterial pressure which, when raised, retards the opening of the tricuspid valve and proportionately prolongs the IIp-T interval; and (3) the heart rate which is inversely related to the duration of the IIp-T.

A table, which uses the IIp-T interval and the heart rate to calculate the systolic pulmonary arterial pressure by external graphic recordings, is presented and the results on 120 cases are included. The figures are compared with those obtained in the same patients by cardiac catheterization.

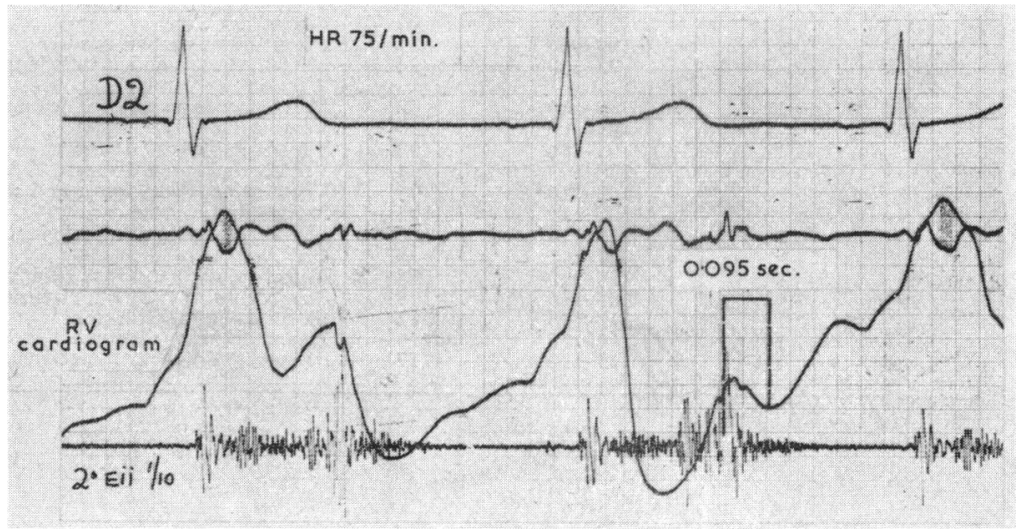

FIG. 10.-Case 27 from Table IV. IIp-T 0.095 sec., heart rate 75 per minute. Calculated systolic pulmonary arterial pressure $60-65 \mathrm{~mm}$. $\mathrm{Hg}$; cardiac catheterization $62 \mathrm{~mm}$. $\mathrm{Hg}$. 


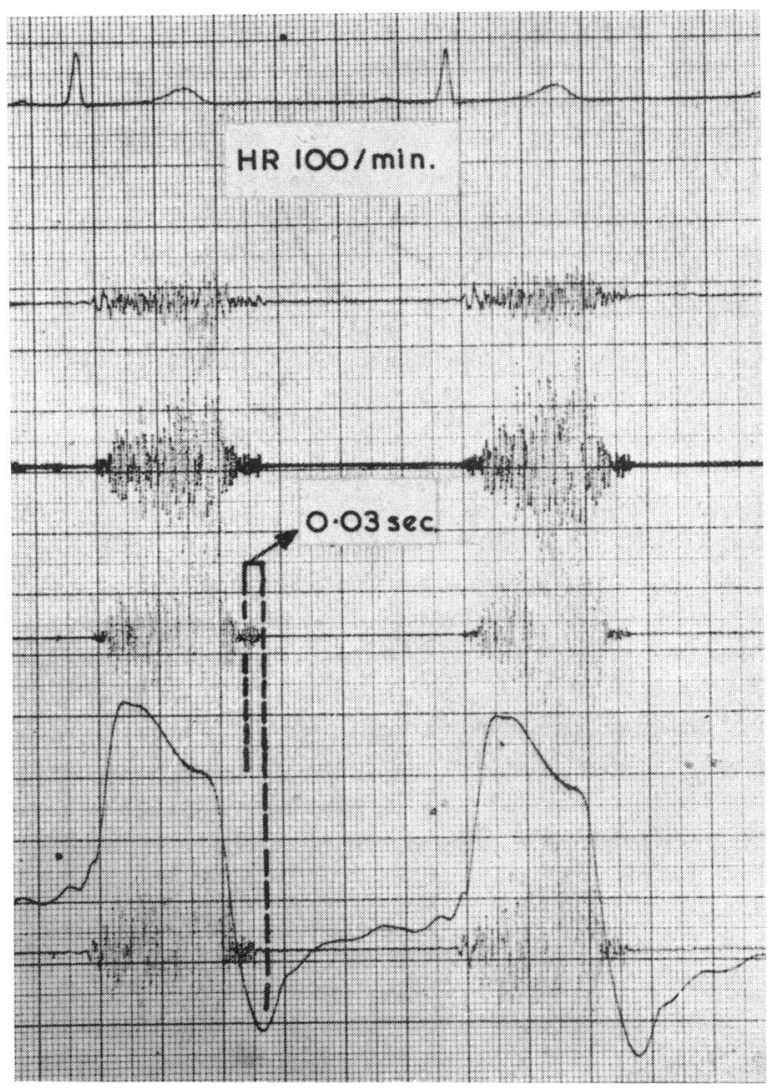

FIG. 12.-Case 4 from Table III. IIp-T $0.03 \mathrm{sec}$, heart rate 100 per minute. Calculated systolic pulmonary arterial pressure less than $30 \mathrm{~mm}$. $\mathrm{Hg}$; cardiac catheterization $12 \mathrm{~mm}$. $\mathrm{Hg}$.

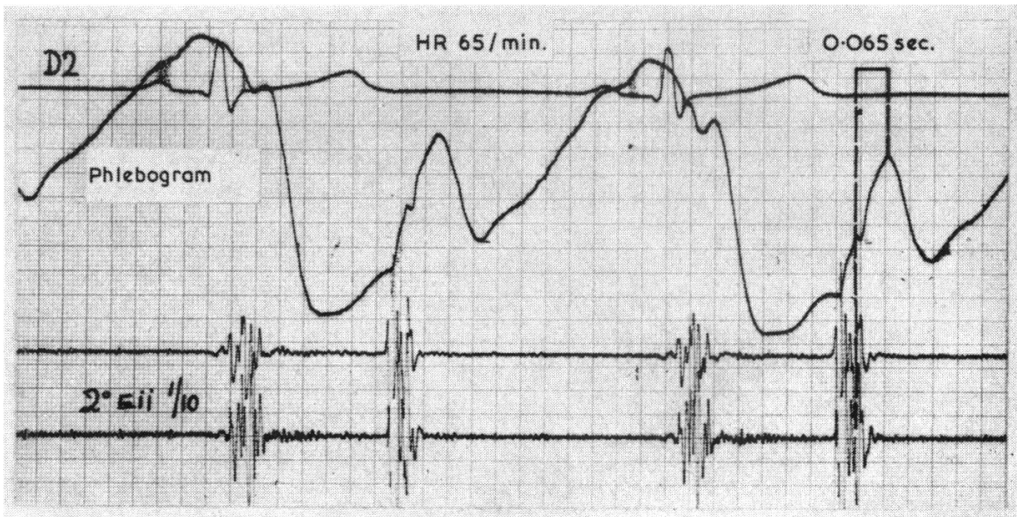

Fig. 13.-Case 1 from Table II. IIp-T $0.065 \mathrm{sec}$, heart rate 65 per minute. Calculated systolic pulmonary arterial pressure less than $30 \mathrm{~mm}$. Hg. No heart disease. 


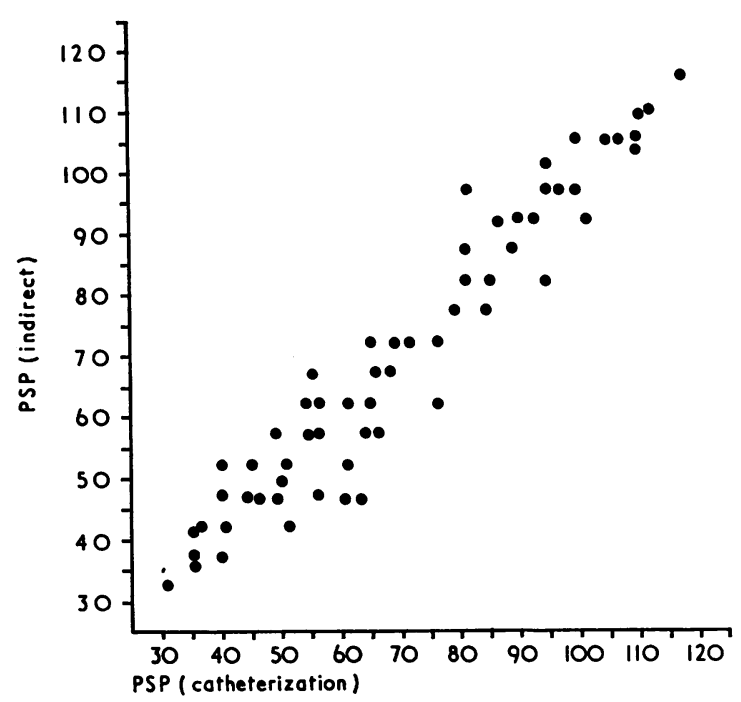

FIG. 14.-Correlation of the systolic pulmonary arterial pressure of 61 cases from Table IV by external graphic registrations and cardiac catheterization. $\mathrm{PSP}=$ pulmonary systolic pressure.

I would like to thank Dr. Ignacio Chavez, Rector of the University of Mexico, for his help and continuing encouragement, and Dr. Bernardo Fishleder, Dr. Teodoro Cesarman, and Dr. Jorge Espino-Vela, from the Institute of Cardiology, Mexico, for their guidance and for making available the facilities to conduct this work, and Dr. David Golde of McGill University, Montreal, Canada, for the translation from the original Spanish.

\section{REFERENCES}

Burstin, L. (1963). Un nuevo método para la determinación de la presión en arteria pulmonar por registros gráficos externos. Memorias IV Congreso Mundial de Cardiol. México, 1962, Vol. 1B, p. 387.
Fishleder, B. L., and Friedland, Ch. (1957). La fonocardiografía en las cardiopatías congénitas. Princ. cardiol. (Méx.), 4, 285.

Hartman, H. (1960). The jugular venous tracing. Amer. Heart f., 59, 698.

Leatham, A., and Gray, I. (1956). Auscultatory and phonocardiographic signs of atrial septal defect. Brit. Heart f., 18, 193.

Luisada, A. A. (1953). The Heart Beat. Hoeber, New York.

Prati, P. L., Rivi, A., Fontana, G., Silingardi, V., and Puviani, G. (1964). Deduzione fonomeccanocardiografiche relative alla durata del rilasciamento isometrico ventricolare nell'uomo. Folia cardiol. (Milano), 23, 549. 